${ }^{\circledR}$ Entomologica Fennica. 24 March 2000

\title{
Hylobius species (Coleoptera: Curculionidae) from Siberia and the distribution patterns of adults feeding in Scots pine stands
}

\author{
Andrei V. Gourov
}

Gourov, A. V. 2000: Hylobius species (Coleoptera: Curculionidae) from Siberia and distribution patterns of adults feeding in Scots pine stands. - Entomol. Fennica 11: 57-66.

Seven Hylobius species are known from Siberia, while the occurrence of three of them is doubtful. Information available about the supplementary feeding of adult weevils is reviewed. It is likely that $H$. abietis and $H$. albosparsus are the only species of economic significance in this territory. In the northern forest-steppe zone, adult weevils usually prefer to feed separately on isolated or border young trees under the canopy of light Scots pine stands, but avoid the undercanopy regeneration in the dense stands. In the southern taiga zone, adults are abundant on cutover areas where they feed in clumps of young regeneration. In fresh clearcuts, up to $100 \%$ of juvenile trees may be damaged by the feeding of weevils, whereas the damage intensity declines sharply with the distance to the clearcut. An edge effect in the distribution of adult weevils needs verification and, probably, is time-dependent. Inside the stands, the crowns of mature trees may constitute an additional food niche for adults if the usual sources and preferred environmental conditions are not available.

Andrei V. Gourov, Laboratory of Forest Zoology, V.N. Sukachev Institute of Forest, Siberian Branch of the Russian Academy of Sciences, 660036 Krasnoyarsk, Akademgorodok, Russia. (Present address and Correspondence: Istituto di Entomologia Agraria, Universitá di Padova, Agripolis, Via Romea, 16, 35020 Legnaro (PD), Italy. Tel. (049) 8272801, Fax (049) 8272810, E-mail: ento@ipdunidx.unipd.it).

Received 8 January 1997, accepted 7 December 1999

\section{Introduction}

Most of the species of the genus Hylobius (Coleoptera: Curculionidae) are widespread pests of boreal coniferous forests. Several of them are of great importance in forestry and received much attention (Luk'yanovich \& Ter-Minasyan 1955, Baker 1972, Eidmann 1974, Furniss \& Carolin 1978, Bevan 1987). The role of Hylobius species constantly increases due to the development of some sylvicultural practices at a large scale. However, certain aspects of the biology and ecology of these weevils still remain unclear.

Two important features characterize this dendrophagous group. (1) Hylobius weevils can be related to xylophages on the basis of larval feeding because the larvae are oligophagous woodborers on the roots of conifers. That is why, their 
distribution is generally dependent on the existence and volume of the food resources (Eidmann 1985). On the other hand, supplementary feeding of free-living adults is more significant economically and depends on numerous environmental factors. Thus, the distribution patterns, food preferences and behavioural features of images are of greater importance than those of larvae. (2) Polyphagy on conifers is a likely characteristic of the adults of dendrophagous Hylobius species. Consequently, they can be considered as relatively independent of both the distribution of the primary host plants and the occurrence of preferred food sources.

Apparently, the first ecological descriptions of coniferous weevil guilds were done for the Eastern Siberia during the 50's (Florov 1950, 1951, Rozhkov 1955, 1957). Later, Petrenko (1965) and Isaev (1966) provided some data for Jakutiya (Northern Siberia), and for Priamur'e and the adjacent Siberian provinces. Rozhkov (1970) described the situation with the Siberian larch forests of the region. A short general review of this group was prepared by Opanasenko (1976), and certain information on the subject has been provided by Bogdanova (1985), and Gourov (1987a) in relation to the Scots pine stands in the Western and Central Siberia.

In this paper, I will shortly reexamine the present data on Hylobius weevils recorded from Siberia. Emphasis of the paper will be put on the comparison between the distribution patterns of the main Hylobius species as well as some related coniferous weevils in Scots pine stands of the northern forest-steppe and southern taiga zones of Siberia.

\section{Material and methods}

Distribution and ecology of coniferous weevils were surveyed in coniferous stands of Central Siberia, mainly in Krasnoyarsk province, in 1978-1986 and in Ust'-Ilimsk district of Irkutsk area in 1987-1988. Two typical pine woodland sites were chosen for the key comparison:

(1) semi-taiga Scots pine stands of herbaceous type in the northern forest-steppe, where the economic importance of pine weevil guild is usually negligible;

(2) southern taiga Scots pine stands of true mosses type in the Angara Plateau, where the economic importance of pine weevil guild is high.

Site 1. Yukseevskoe forestry (Bol'shemurtin-sky Forest
Office of the Krasnoyarsk province, $\left.55^{\circ} 22^{\prime} \mathrm{N}, 90^{\circ} 33^{\prime} \mathrm{E}\right)$. Pure, mainly even-aged (about $60-80$ years old) Scots pine stand on the grey forest soils. Predominant density of 0.4 to 0.6 , changing from 0.8 to 0.2 due to irregular selective harvest. The ground cover is dominated mainly by Carex sp. with Brachypodium pinnatum (L.) Beauv. or Vaccinium vitis-idaea L. as codominants.

Plot 1. Open (0.2-0.4), about 70 year old stand neighbouring upon a mesophytic meadow. Undercanopy pine regeneration (15-20 years old) abundant, up to 12, 000 trees/ ha, occupying also the adjacent meadow belt. Regeneration occurred within the large clumps and thus, the forest border was fuzzy and hardly distinguishable from the border line of mature trees.

The observations were performed during June 1982 in the inner forest $250 \mathrm{~m}$ away from the border, and at a station located in the meadow. For this, 500 and 450 young pines of 1.5 to $2 \mathrm{~m}$ height were randomly chosen in both positions respectively. The observations involved the careful visual inspection of the stem and crown of chosen trees from the top to the butt. The aim of inspection was to register the occurrence of dendrophagous insects as well as all traces of their activity. The low branches of mature trees were also randomly surveyed to search for weevils. In addition, 10 mature trees with a stem no thicker than $20 \mathrm{~cm}$ dbh were randomly chosen within the stand for tree-beating procedures. Tree-beating was performed using a wooden hammer weighing as much as $20 \mathrm{~kg}$. A white sateen cover of $10 \mathrm{~m}$ in diameter was put on the ground under tree crown to check all insects that fell from the tree.

Plot 2. The location was situated $6 \mathrm{~km}$ away from Plot 1. It was a dense (06-08), about 60 year old stand neighbouring a small, about 2 ha, cutover area of 0.5 years. The undercanopy pine regeneration of 15 to 20 years was not abundant $(<$ 6. $000 / \mathrm{ha}$ ), and occurred mainly in small gaps. There were also scattered groups of young pines in the cutover area and along an abrupt forest border.

The observations were performed during June 1982 in the inner forest $300 \mathrm{~m}$ away from the border, in the centre of a cutover area, and along its border. For this, 50 young pines of 1.5 to $2 \mathrm{~m}$ height were randomly chosen and visually inspected in every position. In addition, 10 mature trees with a stem no thicker than $20 \mathrm{~cm}$ dbh were randomly chosen within the stand for tree-beating procedure. Both the visual inspection of trees and tree-beating procedure were similar to those in Plot 1.

Site 2. Nevonskoe and Karapchanskoe forestries (Ust'Ilimsky Forest Office of the Irkutsk area, $58^{\circ} \mathrm{N}, 103^{\circ} \mathrm{E}$ ). Pure, mainly even-aged (about 80 year old) Scots pine stands on the heavy, red loam soils. Predominant density of 0.6 to 0.8 . Ground cover dominated mainly by true mosses (e.g., Pleurozium schreberi (Brid.) Mitt.) with V. vitis-idaea as codominant.

Plot 1. Stand next to 2 year old cutover area originating from entire harvest with use of heavy machinery. Undercanopy regeneration mainly of 10-15 year old, not abundant (< 4. 000/ha), and occurring in small gaps. There were also clustered as well as scattered young pines in the cutover area. The part of cutover area and of adjacent pine stand were subjected to strong surface fire in the previous year.

The observations were performed at the beginning of 
July 1987. Five clumps of young pines of 1 to $1.5 \mathrm{~m}$ height were randomly chosen in the cutover territory at a distance no less than $50 \mathrm{~m}$ away from the border. The area, total number of trees and tree density (trees/ $1 \mathrm{~m}^{2}$ ) were measured for every clump. From 15 till 27 pines (105 trees in total) were randomly chosen within the clumps and visually inspected. In parallel, 65 scattered young pines were sampled in the cutover area at the same distance from the border.

Due to the absence of dense regeneration under the canopy of mature pines, four fuzzy groups of young trees were chosen inside the stand. Two groups were situated at distances of $30 \mathrm{~m}$ and $70 \mathrm{~m}$ away from the cutover area, whereas the others were chosen $25 \mathrm{~m}$ and $60 \mathrm{~m}$ away from the burned clearcut. The groups were composed of $26,74,27$, and 60 young pines respectively. Average height of the trees was similar to that in the cutover area. In addition, 10 mature trees with a stem no thicker than $20 \mathrm{~cm}$ dbh were chosen within the stand for tree-beating procedure. Both visual inspection of trees and tree-beating procedure were similar to those described above.

Plot 2. Stand was next to a 7-year old cutover area originating from the entire harvest. Two years after the harvest, this area was recultivated with Scots pine. Two year old saplings were planted along the furrows of $70 \mathrm{~m}$ to $100 \mathrm{~m}$ length, parallel to an abrupt forest border. The disposition of furrows was not regular and the distance between them varied from $2.5 \mathrm{~m}$ to $10 \mathrm{~m}$ according to local conditions. The distance between seedlings in rows was $0.85 \mathrm{~m}$. The young plantation was attacked by $H$. abietis and $H$. albosparsus just after planting, and only about $40 \%$ of the pines were alive by the time of observations (mid July 1987).

Observations were performed along eight parallel rows of pines, beginning with the closest to the mature stand (50 $\mathrm{m}$ away from the border). With one exception, the rows were chosen at $20 \mathrm{~m}$ intervals, and the last row was situated $200 \mathrm{~m}$ away from the border. The total number of young pines and the number of alive specimens were calculated. All trees were inspected visually to register the occurrence of weevils and/ or marks of their feeding.

Statistical analysis. The mean densities of weevils per sampled tree and the mean percentage of damaged trees in situations under study were compared by $\chi^{2}$ test. The Kolmogorov-Smirnov "goodness-of-fit-test" was used to analyse the data on the Scots pine plantation damaged by Hylobius spp.

\section{Results and Discussion}

\subsection{The genus Hylobius in Siberia: a review}

At present, 13 species of Hylobius are known from the former USSR (Arnoldi et al. 1965), of which 7 species have been recorded from Siberia, between Ural Mountains and the Far East (Table 1). Information on most of them is limited and needs some correction.

Hylobius abietis Linnaeus, the large pine weevil, is the more widespread, abundant and economically important species in Siberia (Opanasenko 1976). It has been recorded in all the $\mathrm{Si}-$ berian vegetation zones characterized by the presence of Pinus sylvestris L. and P. sibirica Du Tour stands. In Siberia, supplementary feeding of the imago was noticed, besides Scots pine, on the Siberian stone pine (Tovkach 1968), and rarely on Larix sibirica Ledeb. (Rozhkov 1970) and Abies sibirica Ledeb. (Luk'yanovich \& Ter-Minasyan 1955).

Usually, the population density of $H$. abietis is low, but the population may increase significantly because the weevils quickly aggregate in territories which have became available for the development of larvae (Florov 1950, Turchinskaya $\&$ Kostyuk 1974). This may explain the abnormally high abundance and damage of this species which were recorded in both the natural young Scots pine stands of Western Siberia (Egorov 1958; Krivetz 1998) and the cutover areas of Eastern Siberia (Florov 1950, Rozhkov 1957, Gourov, unpubl.).

Hylobius albosparsus Motschulsky, the larch root weevil, is a Trans-Siberian species that reaches the North-Eastern areas of the European part of Russia (Arnoldi et al. 1965). It is common in the larch forests of Eastern Siberia, but was also noticed in the Southern, Central and Northern regions of Siberia.

The ecology of $H$. albosparsus has not been carefully investigated. Apparently, the species prefers larch forests (Rozhkov 1970) and, to a lesser degree, dark coniferous stands of mixed composition. Imaginal feeding was noticed on young trees of Picea spp. (Luk'yanovich \& Ter-Minasyan 1965), Larix spp. (Petrenko 1965, Rozhkov 1970, Galkin 1971, Ivliev, Kononov \& Malahova 1973), Pinus spp. (Rozhkov 1957, Petrenko 1965, Zemkova 1963, Galkin 1966) and A. sibirica (Gourov \& Tagliapietra 1997). The economical significance of $H$, albosparsus is lower than that of large pine weevil, although a damage of larch forests by this species is known (Arnoldi et al. 1965).

Hylobius pinastri Gyllenhal, the root coniferous weevil, is a common but not abundant spe- 
Table 1. Major characteristics of Hylobius species observed in Siberia.

\begin{tabular}{|c|c|c|c|c|c|c|}
\hline Species & $\begin{array}{l}\text { Geographic range in } \\
\text { Siberia }\end{array}$ & Vegetation zone & $\begin{array}{l}\text { Relative } \\
\text { abundance* }\end{array}$ & Host plants $^{\dagger}$ & $\begin{array}{l}\text { Food sources } \\
\text { of adults }\end{array}$ & $\begin{array}{l}\text { Relative economi } \\
\text { importance }{ }^{*}\end{array}$ \\
\hline $\begin{array}{l}\text { Hylobius abietis } \\
\text { Linné }\end{array}$ & All Siberia & $\begin{array}{l}\text { From steppe to } \mathrm{N} \mathrm{t} \\
\text { aiga zone }\end{array}$ & +++ & $\begin{array}{l}\text { Pinus spp., Picea spp., } \\
\text { Larix spp., Abies spp., } \\
\text { deciduous trees }\end{array}$ & St/ph, br, sh, b, n & +++ \\
\hline $\begin{array}{l}\text { Hylobius albosparsus } \\
\text { Motschulsky }\end{array}$ & $\begin{array}{l}C \text { and E Siberia, N part } \\
\text { of W Siberia }\end{array}$ & $\begin{array}{l}\mathrm{N} \text { forest-steppe and } \\
\text { all taiga zones }\end{array}$ & ++ & $\begin{array}{l}\text { Pinus spp., Picea spp., } \\
\text { Larix spp., A. Sibirica }\end{array}$ & St/ph, br, sh, n & ++ \\
\hline $\begin{array}{l}\text { Hylobius gebleri } \\
\text { Boheman }\end{array}$ & $\begin{array}{l}S \text { mountain regions } \\
\text { of Siberia }\end{array}$ & $S$ mountain taiga & ++ & $\begin{array}{l}\text { Bergenia crassifolia, } \\
\text { Rhodiola rosea, Larix } \\
\text { spp. (?) }\end{array}$ & $(?)$ & + \\
\hline $\begin{array}{l}\text { Hylobius haroldi } \\
\text { Faust }\end{array}$ & E Siberia (?) & S taiga & - & $\begin{array}{l}\text { Pinus spp., Picea spp., } \\
\text { Larix spp. }\end{array}$ & St/ph, br, sh & + \\
\hline $\begin{array}{l}\text { Hylobius piceus De } \\
\text { Geer }\end{array}$ & $W(?)$ and $C(?)$ Siberia & $\begin{array}{l}\mathrm{N} \text { forest-steppe, } \mathrm{M} \\
\text { and } \mathrm{N} \text { taiga zones }\end{array}$ & - & $\begin{array}{l}\text { Pinus spp., Picea spp., } \\
\text { Larix spp., Abies spp. }\end{array}$ & St/ph, sh & - \\
\hline $\begin{array}{l}\text { Hylobius pinastri } \\
\text { Gyllennhal }\end{array}$ & All Siberia & $\begin{array}{l}\text { Forest-steppe and } \\
\text { all taiga zones }\end{array}$ & + & $\begin{array}{l}\text { Pinus sylvestris, Picea } \\
\text { obovata, Larix spp. }\end{array}$ & $\mathrm{St} / \mathrm{ph}, \mathrm{br}, \mathrm{sh}, \mathrm{b}, \mathrm{n}$ & + \\
\hline $\begin{array}{l}\text { Hylobius } \\
\text { transversovittatus } \\
\text { Goeze }\end{array}$ & $(?)$ & (?) & - & Lythrum salicaria & (?) & - \\
\hline
\end{tabular}

*+++ high; ++ medium; + low; - rare or absent. +Host plants for both larval and adult feeding are given. ${ }^{*}+++$ high; ++ medium; + low; - no information. C - Central; E Eastern; M - Mid; N - Northern; S - Southern; W - Western. B - buds; br- branches; $n$ - needles, sh - shoots; st/ph - stem phloem. 
cies. It has been observed in coniferous forests with a significant proportion of Scots pine in the Western, Central and Eastern Siberia. The ecology of $H$. pinastri received little attention because of its limited economical significance. Supplementary feeding of imago has been observed on Scots pine (Florov 1950, Rozhkov 1957, Opanasenko 1976), Siberian larch (Isaev 1966, Rozhkov 1970), spruce, Picea obovata Ledeb. (Gourov \& Tagliapietra 1997), and fir (Krivetz 1998). Apparently, it avoids northern regions, because Petrenko (1965) did not find it in Jakutiya.

Hylobius piceus De Geer, the spruce root weevil, is a common species of coniferous forests in Europe, including the European part of Russia (e.g., Arnoldi et al. 1965). The occurrence of this species in Siberia is questionable. Earlier, Luk'yanovich \& Ter-Minasyan (1955) noted that all findings of $H$. piceus in the extreme NorthEast of Europe and in Siberia must be related to H. albosparsus. Later, Rozhkov (1970) suggested the species occurs in the western range of Siberian larch, but its presence on that territory has not been confirmed yet. Incidentally, Eidmann (1974) mentioned it for Siberia (without mention of the region). I collected only two specimens in the Northern forest-steppe zone of Central Siberia in 1980 (Gourov 1987a), but they could have been brought there with some timber materials. Within the limits of its natural range, the imaginal feeding has been observed on Larix spp., Picea spp. and Scots pine (Arnoldi et al. 1965, Eidmann 1974, Valenta \& Zhegas 1978, Ozols 1985).

Hylobius haroldi Faust, the eastern root weevil. Taxonomic position of the species remains uncertain. Some authors consider it as a subspecies, H. abietis haroldi (Fang San-Yang 1993), whereas a recent review confirmed the validity of species status (Egorov et al. 1996).

This species was noticed previously in the Far East of Russia (Primor'e, Priamur'e) on $P$. sylvestris and $P$. tabulaeformis Carr. (= P. funebris Komar.) (Kurentzov 1950, 1953), P. koraiensis Sieb. et Zucc. (Kurentzov 1958) and Larix dahurica Turcz. (= L. gmelinii (Rupr.) Litvin) (Isaev, 1966). Recently, P. koraiensis and Siberian dwarf pine, $P$. pumila (Pall.) Rgl. were mentioned as main hosts of this weevil (Egorov et al. 1996). It is also recorded from the Central and South-Western China in stands with $L$. sibirica, $P$. obovata, $A$. sibirica and $P$. sibirica, and the damage by this species was noticed for $P$. koraiensis stands (Fang San-Yang 1993). Apparently, the species is also present in the extreme East of Siberia and may have some economic importance similar to $\mathrm{H}$. albosparsus.

Hylobius gebleri Boheman is one of the Hylobius species that develops on undershrub vegetation. The species is probably a Trans-Siberian weevil, because it has been recorded also from Japan (Luk'yanovich \& Ter-Minasyan 1955). The larva usually develops on the roots of important medicinal plants, the Siberian tea, Bergenia crassifolia (L.) Fritsch. (Saxifragaceae) (Arnoldi et al. 1965) and the rose-root stone-crop, Rhodiola rosea L. (Crassulariaceae) (Kazarinova \& Opanasenko 1973; Kuznetzova \& Krivetz 1981). Introduction of $H$. gebleri with its host plants into the St. Petersburg area is known (Arnoldi et al. 1965). In addition, Rozhkov (1970) observed adults of this weevil in the larch stands of the Baikal area and suggested that it may damage the bark of young larch shoots during phases of supplementary feeding.

Hylobius transversovittatus Goeze is a species developing on the roots of Lythrum salicaria L. (Lythraceae). Records of this species in Siberia (Luk'yanovich \& Ter-Minasyan 1955, Krivetz 1998) probably need a revision.

As mentioned above, only two Hylobius species are economically significant forest pests in Siberia, but the effective participation of $\mathrm{H}$. abietis, $H$. albosparsus, $H$. pinastri and, probably, $H$. harold $i$ in the coniferous weevil guilds makes them also objects of investigation even if their population densities are limited. The first three widespread Hylobius species were recorded constantly (Florov 1950, Rozhkov 1957, Isaev 1966, Gourov 1987a). The absence of $H$, albosparsus in the Florov's list (Florov 1950) may represent a mistake. However, it was not always possible during my observations to find all the usual Hylobius species simultaneously in a one plot. H. abietis followed by P. castaneus De Geer was the general. 


\subsection{Distribution patterns}

Site 1. Northern forest-steppe zone. Members of the pine weevil guild dominated by $P$. castaneus, were not abundant in undisturbed, light $(0.2-0.4)$ stands, and their total mean density varied between $0.011 \pm 0.1$ and $0.106 \pm 0.3$ individuals per young tree (Table 2). Most weevils preferred to feed separately on undercanopy regeneration. Within the stand, the mean number of beetles per tree was significantly higher $\left(\chi^{2}, \mathrm{P}<0.01\right)$ than in the pine clumps growing on adjacent open areas (Table 2). According to visual observations inside the forest, adults of $H$. abietis and most of $P$. castaneus were observed on separated young trees and on the borders of clumps.

Weevils were not found at all on young trees inside the dense $(0.6$ - 08) mature stand but were rather abundant in neighbouring fresh cutover areas and along the forest border $(0.44 \pm 0.5$ and
$0.5 \pm 0.8 \mathrm{exempl} . /$ tree, respectively). In this case, the guild was dominated by $H$. abietis which showed a statistically significant edge effect in its distribution $\left(\chi^{2}, \mathrm{P}<0.05\right)$ (Table 2 ) and performed group-feeding. At the same time, the total mean numbers of all weevil species per tree did not differ significantly between cutover and border positions $\left(\chi^{2}, \mathrm{P}=0.66\right)$.

Tree-beating procedures revealed the presence of $H$. abietis in the crown of mature pines in both light and dense stands. The total number of beetles caught from 10 trees was significantly higher in dense $(\mathrm{n}=32)$ than in light stands $(\mathrm{n}=15)\left(\chi^{2}\right.$, $\mathrm{P}<0.05)$. Adults of $H$. pinastri were not found after tree-beating, but were observed accidentally on the lower branches of mature trees.

Site 2.Southern taiga zone. Both $H$. abietis and $H$. albosparsus were found during tree-beating within the stand. A significantly lower number of H. abietis was caught from 10 trees in the south-

Table 2. Number of coniferous weevils in the clumps of young Scots pine trees under the canopy of mature stands of different density and in the adjacent open areas. Yukseevskoe forestry, Forest Office of Bol'shaya Murta, Krasnoyarsk province, June 1982.

Light stand (0.2-0.4)

\begin{tabular}{|c|c|c|c|c|c|c|c|}
\hline \multirow[t]{2}{*}{ Species } & \multicolumn{3}{|c|}{ Inside the forest (500 trees) } & \multicolumn{4}{|c|}{ Open area (450 trees) } \\
\hline & $\begin{array}{l}\text { Total } \\
\text { weevils }\end{array}$ & $\mathrm{N} /$ tree & $\pm \mathrm{SD}$ & $\begin{array}{l}\text { Total } \\
\text { weevils }\end{array}$ & $\mathrm{N} /$ tree & $\pm \mathrm{SD}$ & $x^{2}$ \\
\hline Hylobius abietis & 4 & 0.008 & 0.099 & 0 & - & - & n.s. \\
\hline Pissodes castaneus & 41 & 0.082 & 0.275 & 2 & 0.004 & 0.066 & $P<0.01$ \\
\hline Brachonyx pineti & 6 & 0.012 & 0.109 & 3 & 0.007 & 0.081 & n.s. \\
\hline Anthonomus varians & 2 & 0.004 & 0.063 & 0 & - & - & n.s. \\
\hline Total guild & 53 & 0.106 & 0.308 & 5 & 0.011 & 0.105 & $P<0.01$ \\
\hline
\end{tabular}

Dense stand $(0.6-0.8)$

\begin{tabular}{|c|c|c|c|c|c|c|c|}
\hline \multirow[t]{2}{*}{ Species } & \multicolumn{3}{|c|}{ Forest border (50 trees) } & \multicolumn{4}{|c|}{ Cutover area (50 trees) } \\
\hline & $\begin{array}{l}\text { Total } \\
\text { weevils }\end{array}$ & $\mathrm{N} /$ tree & $\pm \mathrm{SD}$ & $\begin{array}{l}\text { Total } \\
\text { weevils }\end{array}$ & $\mathrm{N} /$ tree & $\pm \mathrm{SD}$ & $\chi^{2}$ \\
\hline Hylobius abietis & 18 & 0.360 & 0.802 & 6 & 0.120 & 0.328 & $P<0.05$ \\
\hline Pissodes castaneus & 3 & 0.060 & 0.239 & 10 & 0.200 & 0.451 & n.s. \\
\hline P. pini & 0 & $=$ & $=$ & 2 & 0.040 & 0.198 & n.s. \\
\hline P. piniphilus & 4 & 0.080 & 0.274 & 0 & - & - & n.s. \\
\hline Magdalis sp. & 0 & $=$ & - & 4 & 0.080 & 0.274 & n.s. \\
\hline Total guild & 25 & 0.500 & 0.814 & 22 & 0.440 & 0.541 & n.s. \\
\hline
\end{tabular}


ern taiga dense stand $(\mathrm{n}=10)$ in comparison with the northern forest-steppe (Site $1, \mathrm{n}=32)\left(\chi^{2}, \mathrm{P}<\right.$ $0.01) . H$. albosparsus was more abundant $(\mathrm{n}=$ 23) than $H$. abietis $(n=10)$ in the mature crowns of taiga forest $\left(\chi^{2}, \mathrm{P}<0.05\right)$. A few specimens of $H$. pinastri were caught during the visual inspection of the forest border alone.

In the cutover area, the pine weevils were dominated by $M$. fermaneki Reitter and $P$. castaneus. In the clearcut, adults of all species were significantly more abundant $(\mathrm{n}=115)$ than within the adjacent dense stand $(n=8)\left(\chi^{2}, P<0.01\right)$. Inside the dense stand, weevils were found only $25-30$ $m$ away from the border (Table 3 ). The clumps of young pines surviving on the cutover area after the harvest were more intensively colonized by weevils than separated trees $\left(\chi^{2}, \mathrm{P}<0.01\right)$. Nevertheless, all separated trees and trees in clumps were damaged by Hylobius, and the intensity of attack declined sharply inside the forest (Table 3).

In the older, 7-year old clearcut the damage of planted pines was also high but did not reach the 100 percent level. The percentage of alive pines per row varied between 8.5 and 36.4 , and about $9,1 \%$ of the inspected trees showed only

Table 3. Number of coniferous weevils observed on young Scots pine regeneration in the dense south taiga stands and on adjacent cutover areas. Nevonskoe forestry, Ust'-llimsky Forest Office, Irkutsk area, July 1987.

\begin{tabular}{lcccc}
\hline & 2-years old clearcut & Dence (0.6-0.8) mature stand \\
\hline & Trees in clumps & Separated trees & $\begin{array}{c}\text { Fuzzy clumps } \\
25-30 \mathrm{~m} \text { far from } \\
\text { the clearcut }\end{array}$ & $\begin{array}{l}\text { Fuzzy clumps } \\
60-70 \mathrm{~m} \text { far from } \\
\text { the clearcut }\end{array}$ \\
\hline Number of sampled trees & 105 & 65 & 53 & 134 \\
\hline $\begin{array}{l}\text { Number of trees damaged } \\
\text { by Hylobius spp.: }\end{array}$ & 105 & 65 & 22 & 6 \\
$\begin{array}{l}\text { Total } \\
\text { \% from sampled trees }\end{array}$ & 100 & 100 & 42 & 4 \\
\hline Number of weevils caught* & 93 & 22 & 8 & 0 \\
\hline
\end{tabular}

* In the clearcut, the weevils complex was dominated (in the period of observation) by M. fermaneki and to a lesser degree by $P$. castaneus whereas $H$. abietis was observed as several exemplars only. Inside the forest, only $P$. castaneus was observed.

Table 4. Damage of 5 year old Scots pine plantation by Hylobius abietis and $H$. albosparsus in relation to the nearest border of mature stand. Karapchanskoe forestry, Ust'-llimsky Forest Office, Irkutsk area, July 1987.

\begin{tabular}{|c|c|c|c|c|c|c|}
\hline \multirow{2}{*}{$\begin{array}{c}\text { No of row } \\
1\end{array}$} & \multirow{2}{*}{$\begin{array}{l}\text { Distance from } \\
\text { the border, } m\end{array}$} & \multirow{2}{*}{$\begin{array}{l}\text { Length of } \\
\text { row, m } \\
100\end{array}$} & \multicolumn{2}{|c|}{$\begin{array}{l}\text { Number of alive trees } \\
\text { exampl. \% from total number }\end{array}$} & \multicolumn{2}{|c|}{$\begin{array}{l}\text { Trees with fresh Hylobius damage } \\
\text { exampl. \% from number of alive }\end{array}$} \\
\hline & & & 43 & 36.4 & 4 & 9.3 \\
\hline 2 & 70 & 100 & 16 & 13.6 & 4 & 25.0 \\
\hline 3 & 90 & 100 & 23 & 19.5 & 2 & 8.7 \\
\hline 4 & 120 & 90 & 34 & 32.1 & 5 & 14.7 \\
\hline 5 & 140 & 100 & 10 & 8.5 & 1 & 10.0 \\
\hline 6 & 160 & 70 & 17 & 20.7 & 0 & 0 \\
\hline 7 & 180 & 100 & 38 & 32.2 & 2 & 5.3 \\
\hline 8 & 200 & 100 & 26 & 22.0 & 0 & 0 \\
\hline $\begin{array}{l}\text { Average } \\
+S D\end{array}$ & & & $\begin{array}{r}25.88 \\
+11.61\end{array}$ & $\begin{array}{r}23.13 \\
+9.74\end{array}$ & $\begin{array}{r}2.25 \\
+1.91\end{array}$ & $\begin{array}{r}9.13 \\
+8.15\end{array}$ \\
\hline
\end{tabular}


fresh traces of Hylobius attack (Table 4). The distribution of both previous and fresh damages was irregular and did not appear to follow any pattern in relation to the distance from the nearest forest border (Kolmogorov-Smirnov goodness of fit test, $\mathrm{P}>0.05)$.

\section{Conclusions}

Concerning taxonomy and biogeography of $H y-$ lobius species in Siberia, future efforts could concentrate on: (a) the verification of the range of $H$. haroldi; (b) identification of the interface between the areas of $H$. piceus and $H$. albosparsus; (c) refinement of the total range and determination of food plants for the adults of $H$. gebleri and $H$. transversovittatus (Table 1).

A low abundance of Hylobius spp. and related weevil species in both study areas was shown (Table 2,3). This confirms the observations from the southern taiga zone at the same seasonal period by Rozhkov (1957) and agrees with a results made by Gourov (1987a) for the northern foreststeppe of Siberia. The preference of the weevils for the undercanopy regeneration in the light forest-steppe stands (Table 2) could be explained by (a) the constant occurrence and regular distribution of young pines; (b) the lower resistance of undercanopy regeneration in comparison with open-growing pines due to the competition with mature pines for water and mineral resources; and (3) the local microclimate (Gourov 1987a). The latter factor could be also responsible for the higher abundance of weevils on separated and "border" young trees inside the forest (Gourov 1987b).

The absence of weevils in the understory regeneration of dense stands could be related to the avoidance of (1) shaded habitats, and (2) the irregularity of the distribution of the potential food plants by the beetles, confirming previous observations on $H$. abietis by Florov (1950) and Rozhkov (1957). Damage of young pines, that reached about $100 \%$ on the clearcut, sharply decreased inside the forest (Table 3). Such avoidance of forest shade and cooler sites by the feeding adults has also been shown in some other $H y$ lobius, Pissodes and Magdalis species (Martin 1964, Kennedy \& Wilson 1971, Stiell \& Berry
1985) and resulted in a lesser degree of damage to the host trees (McLean 1994, Taylor et al. 1994).

The results of tree-beating are also in accordance with this explanation. Adults of $H$. abietis were generally more abundant in mature crowns in the dense stands, and in the southern taiga in particular. The prevalence of $H$. albosparsus upon $H$. abietis in taiga forest could be explained by the higher adaptation of the first species to live in the dense stands and to feed on the thin branches of healthy large trees (Rozhkov 1970). The feeding in large crowns is known also for other Hylobius weevils (Graham \& Knight 1965, Ehrman \& Wasserman 1983). Apparently, in the absence of preferred food sources or the presence of unfavourable undercanopy conditions, the crowns of mature trees may allow an additional food environment for the adults of conifer weevils which normally feed on juvenile trees.

Edge effects observed in the distribution of H. abietis (Table 2) and in some other Hylobius and related coniferous weevils (Rozhkov 1955, Godwin et al. 1957) need verification. On the one hand, a distributional edge effect appears to be usual for most of the dendrophagous insects under normal, nonoutbreak conditions (Gourov 1991), and the investigations may be more fruitful under the conditions of low or, at least, limited density (Gourov \& Petrenko 1986, 1988). On the other hand, in the case of industrial wood harvest, the edge concentration of Hylobius weevils may be temporal, and they can later spread over all the entire fresh cutover area (Table 3) (Eidmann 1968). This may explain the larger damage of seedlings by $H$. congener Dalla Torre, observed at the boundaries of young plantations (Welty \& Houseweart 1985), because of the preliminary stage of cut site colonization. When the population density is high, the distribution of total damage by coniferous weevils appears to be relatively homogeneous (Table 4, as resulting example), despite the more or less specific distribution of the species. Thus, the edge effect, as a feature of coniferous weevil distribution, may be revealed only if the density of these insects does not reach some critical value and if the available food base is not completely involved in the process. 
Acknowledgements. I am grateful to A. Battisti, A. Roques and anonymous referees for critically reading the manuscript. A. Babenko, S. Krivetz and V. Zherihin kindly provided an information on the status of some Hylobius species.

\section{References}

Arnoldi, L. V., Zaslavsky, V. A. \& Ter-Minasyan, M. E 1965: Curculionidae. - In: Bey-Bienko, G. Ya. (ed.), (Keys to the Insects of the European USSR). Vol.II. Coleoptera and Strepsiptera: 485-621. Nauka, Moscow-Leningrad. $668 \mathrm{pp}$. (In Russian)

Baker, W. L. 1972: Eastern forest insects. - Miscellaneous publication No. 1175, U. S. Department of Agriculture, Forest Service, US Government Printing Office. 642 pp.

Bevan, D. 1987: Forest insects. A guide to insects feeding on trees in Britain. - Forestry Commission, Her Majesty's Stationery Office, London. 153 pp.

Bogdanova, D. A. 1985: The snout beetles (Coleoptera, Curculionidae) - pests at pine artificial plantings in Western Siberia. - Izvestiya Sibirskogo Otdeleniya Akademii Nauk SSSR. Ser. Biologicheskaya 3 (18): 59-64. (In Russian, English summary)

Egorov A. B., Zherihin V, V, \& Korotyaev B. A. 1996: Curculionidae. - In: Lehr, P. A. \& Lelej, A. S. (eds.) (Keys to the insects of the Far East of Russia). Vol. 3. Coleoptera. Part 3: 431-524. Nauka, Moscow - St. Petersbourg. 556 pp. (In Russian)

Egorov, N. N. 1958: Insect pests of the belt Scots pine stands in the Western Siberia. - Zool. Zh. 37: 1488-1499. (In Russian, English summary)

Ehrman, L. \& Wasserman, M. 1983: Damage of slash pine female strobili by reproduction weevils. - Florida Entomol. 66: 364-365.

Eidmann, H. H. 1968: Invasion of conifer plantations by radioactively labelled Hylobius abietis L. - In: Isotopes and radiation in entomology. Proc. of IAEA/FAO Symposium (Wien, 1967): 75-84. International Atomic Energy Agency, Vienna.

Eidmann, H. H. 1974: Hylobius Schonh.. - In: Schwenke, W. (ed.), Die Forstschädlinge Europas. Bd.2. Käfer: 275293. Parey, Berlin. 500 pp.

Eidmann, H. H. 1985: Silviculture and insect problems. Z. Angew. Entomol. 99: 105-112.

Fang San-Yang 1993: The eco-geographical distribution of forest-pest insects in China. - Northeast Forestry University, Harbin. 124 pp. (In Chinese, English summary)

Florov, D. N. 1950: (Weevils on conifers in Eastern Siberia (Pissodes, Hylobius)). - Izvestiya Biologo-Geograficheskogo Nauchno-Issledovatel'skogo Instituta pri Irkutskom Gosudarstvennom Universitete 10: 11-29. (In Russian)

Florov, D. N. 1951: (Pests of the Siberian stone pine). Gosudarstvennoe Izdatel'stvo, Irkutsk. 123 pp. (In Russian)

Furniss, R. L. \& Carolin, V. M. 1978: Western forest insects. - Miscellaneous publication No1339, U.S. Department of Agriculture, Forest Service, US Government Printing Office. $654 \mathrm{pp}$.

Galkin, G. I. 1966: (Insect pests of young coniferous generation in the forest stands of the central part of Podkamen- naya Tunguska basin). - In: Cherepanov, A I. (ed.), (Fauna and ecology of arthropods in Siberia): 92-94. Nauka, Novosibirsk. 221 pp. (In Russian)

Galkin, G. I. 1971: (Short review of insect pests of Dahurian larch in the mid part of Nizhnyaya Tunguska basin). In: Kondakov, Yu. P. (ed.), (Problems of protection of taiga forests). Proc. of All-Union Conference: 32-33. V. N. Sukachev Institute of Forest and Wood, Academy of Sciences of the USSR, Krasnoyarsk. 192 pp. (In Russian)

Godwin, P. A., Jaynes, H. A. \& Davis J. M. 1957: The dispersion of radioactively tegged white-pine weevils in small plantations. - J. Econ. Entol. 50: 264-266.

Gourov, A. V. 1987a: (Ecological conditionality of the complex of phytophagous insects in young Scots pine stands in the Northern forest-steppe zone of Central Siberia). Unpublished PhD Thesis. - V. N. Sukachev Institute of Forest and Wood, Academy of Sciences of the USSR, Krasnoyarsk. 311 pp. (In Russian).

Gourov, A. V. 1987b: (Ecological peculiarities of the habitats of phytophagous insects in young Scots pine stands of Krasnoyarsk forest-steppe region). - In: Vladyshevsky, D. V. \& Petrenko, E. S. (eds.), (Ecological evaluation of the habitat of forest animals): 58-68. Nauka, Novosibirsk. 216 pp. (In Russian)

Gourov, A. V. (see Gurov, A. V.) 1991: Preference of dendrophagous insects for forest borders, - In: Baranchikov, Yu. N., Mattson, W. J., Hain, F. P. \& Payne, T. L. (eds.), Forest Insect Guilds: Pattems of interaction with host trees: 50-52. USDA Forest Service General Technical Reports, NE-153. 400 pp.

Gourov (see Gurov), A. V. \& Petrenko, N. M. 1986: Characteristics of leaf consumption by phyllophagous insects in young pine and deciduous forests. - Lesovedenie 4: 15-22. (Translated into English by Allerton Press, Inc., 1987).

Gourov, A. V. \& Petrenko, N. M. 1988: Methods of estimating trophic activity of phyllophagous insects in forest biogeocenoses. - Lesovedenie 5: 15-19. (In Russian, English summary)

Gourov, A.V., \& Tagliapietra, V. 1997: Uncommon cases of damage to young coniferous trees by several Cucrulionoidea species, and possible ecological reasons. - In: Gregoire, J. C., Liebhold, A. M., Stephen, F. M., Day, K. R. \& Salom, S. M. (eds.), Proceedings: Integrating cultural tactics into the management of bark beetle and reforestation pests: 228-243. USDA Forest Service General Technical Report NE-236. 243 pp.

Graham, S. A. \& Knight, F. B. 1965: Principles of forest entomology. McGraw-Hill, New York. 417 pp.

Isaev, A. S. 1966: (Xylophagous insects of the Dahurian larch). Nauka, Moscow. 148 pp. (In Russian)

Ivliev, L. A., Kononov, D. G. \& Malakhova, V. P. 1973: Phytophagous insects of the Larix lubarskii Suk., the relict tree species of the Primorsky province. - Entomofauna of the Far East. Proceedings of the Institute of Biology and Pedology, Far East Science Centre of the Academy of Sciences of the USSR (Vladivostok), new series 9 (112): 20-34. (In Russian, English summary)

Kazarinova, N. F. \& Opanasenko, F. I. 1973: Curculionid beetle, Hylobius gebleri Boh. (Coleoptera, Curculionidae) as a root pest of the rose-root stone-crop. - Iz- 
vestiya Sibirskogo Otdeleniya Akademii Nauk SSSR. Ser. Biologicheskih Nauk 3: 130-133. (In Russian, English summary)

Kennedy, P. C. \& Wilson, L. F. 1971: Pine root collar weevil damage to red pine plantations in Michigan related to host age, temperature, and stand location. - Can. Entomol. 103: 1685-1690.

Krivetz, S. A. 1997: (Ecologo-faunistic review of weevils (Coleoptera: Curculionidae, Apionidae) of the south-eastern part of Western Siberia). Unpublished PhD Thesis. Tomsk State University, Tomsk. 247 pp. (In Russian)

Kurentzov, A. I. 1950: (Insect pests on conifers of Primor'e region). - Trudy Dal'nevostochnogo filiala Academii Nauk SSSR. T.1 (4). Vladivostok. 256 pp. (In Russian)

Kurentzov, A. I. 1953: (Insect pests of forest plantations and control for them in Primor'e and Priamour'e regions). Primorskoe Knizhnoe Izdatel'stvo, Vladivostok. 64 pp. (In Russian)

Kurentzov, A. I. 1958: (Animals of Prikhankaiskaya plain). - In: Kolesnikov, B. P. (ed.) (Materials on the physical geography of the southern Far East of the USSR): 273 296. Vladivostok. 297 pp. (In Russian)

Kuznetzova, N. P. \& Krivetz, S. A. 1981: (The curculionid beetle, Hylobius gebleri Boh. as a pest of the rose-root stone-crop in the Siberian Botanical Garden. - In: Zolotarenko, G. V. (ed.) (Fauna and ecology of the arthropods in Siberia): 159-162. Nauka, Novosibirsk. (In Russian)

Luk'yanovich, F. K. \& Ter-Minasyan, M. E. 1955: Curculiondae. - In: Pavlovsky, E. N. \& Shtakelberg, A. A. (eds.) (Forest pests. A reference book). Vol. II: 592-668. Academy of Sciences of the USSR, Moscow - Leningrad. 672 pp. (In Russian)

Martin, J. L. 1964: The insect ecology of red pine plantations in Central Ontario. II. Life history and control of Curculionidae. - Can. Entomol. 96: 1408-1417.

McLean, J. A. 1994: Silvicultural control of the white pine weevil at the UBC Malcolm Knapp research forest. In: Alfaro, R. I., Kiss, G. \& Fraser, R. G. (eds.) The white pine weevil: biology, damage and management. Proc. of Symp., January 19-21, 1994, Richmond, British Columbia: $248-253$.

Opanasenko, F. I. 1976: (Weevils (Coleoptera: Curculionidae et Rhynomaceridae) of conifers in Siberia). - Trudy Biologicheskogo Instituta Sibirskogo Otdeleniya Akademii Nauk SSSR (Novosibirsk), 18: 223-238. (In Russian)

Ozols, G. 1985: Priedes un egles dendrofägie kukaini Latvijas mezos. Zinätne, Riga. 207 pp. (In Latvian)

Petrenko, E. S. 1965: (Insect pests of the forests stands in Jakutiya). Nauka, Moscow. 167 pp. (In Russian)
Rozhkov, A. S. 1955: (Insect pests of the young Scots pine stands on the cutover areas in Pribaikal'e). Unpublished $\mathrm{PhD}$ thesis. Academy of Science of the USSR, Far East Scientific Centre, Vladivostok. 189 pp. (In Russian)

Rozhkov, A. S. 1957: (On the investigation of seasonal dynamics, abundance, and pest activity of weevils in young Scots pine stands on the cutover areas of Baikal Region - In: Reimers, F. E., (Forest stands and their pests in Eastern Siberia). Trudy Vostochno-Sibirskogo Filiala Akademii Nauk SSSR. Seriya biologicheskaya 5: 138146. Irkutskoe Oblastnoe Knizhnoe Izdatel'stvo, Irkutsk. 163 pp. (In Russian)

Rozhkov, A. S. 1970: Family Curculionidae. - In: Rozhkov, A.S. (ed.), Pests of Siberian larch: 117-126. Israel Program for Scientific Translations, Jerusalem. 393 pp.

Stiell, W. M. \& Berry, A. B. 1985: Limiting white pine weevil attacks by side shade. - For. Chron. 61: 5-9.

Taylor, S. P., Alfaro, R., Delong, C. \& Rankin, L. 1994: The effects of overstory shading on white pine weevil damage to interior white spruce. - In: Alfaro, R. I., Kiss, G. \& Fraser, R. G. (eds.) The white pine weevil: biology, damage and management. Proc. of Symp., January 1921, 1994, Richmond, British Columbia: 254-261.

Turchinskaya, I. A. \& Kostyuk, N. N. 1974: (Insect pests of the young generation of Scots pine under the conditions of high soil humidity). - In: Stratonovich, A. I. (ed.), Sbornyk nauchnych trudov Leningradskogo NauchoIssledovatel'skogo Instituta lesnogo hozyaistva. 21: 100 106. Leningrad. 154 pp. (In Russian)

Tovkach, L. N. 1968: (Main pests and diseases of the young generation of Siberian pine in the Tofalar forestry of Nizhneudinsk district of Irkutsk region). - In: Belov, S. V. \& Kataev, O. A. (eds.), (Forest protection): 120125. Nauchnye trudy Lesotehnicheskoj Akademii imeni S. M. Kirova (Leningvrad), Vol. 115. Leningrad. 144 pp. (In Russian)

Valenta, V. T. \& Zhegas A. K. 1978: (On the question of inventarization and prognosing of the abundance of $\mathrm{Hy}$ lobius weevils). - In: Kairyukshtis, L. A. (ed.), (Protection of coniferous stands from pests and diseases): 25 27. Proc. of All-Union Conference, Kaunas. 287 pp. (In Russian)

Welty, C. \& Houseweart, M. W. 1985: Site influences on Hylobius congener (Coleoptera: Curculionidae), a seedling debarking weevil on conifer plantations in Maine. - Environ. Entomol. 14: 826-833.

Zemkova, R. I. 1963: (On the investigation of insect pests of the Siberian stone pine stands in Western Sayan Mountains.) - In: Zhoukov, A. V. (ed.), (Protection of Siberian forest stands from insect pests): 183-188. Izdatel'stvo Akademii Nauk SSSR, Moscow. 216 pp. (In Russian) 